\title{
Effect of Purple Sweet Potato (Ipomoea Batatas L.) Extract on Glutathione Peroxidase (GPx) Activities in Hepatic House Mice (Mus musculus) After Maximum Physical Exercise
}

\author{
Ayu Elvana1), Herla Rusmarilin²), Ramlan Silaban3), Rika Nailuvar Sinaga4) \\ 1) School of Health Sciences (STIKes) Siti Hajar, Medan, Indonesia \\ 2) Faculty of Agriculture, North Sumatera University \\ 3) Faculty of Mathematics and Science, Medan State University \\ 4) Faculty of Sport Science, Medan State University
}

\begin{abstract}
Background: Physical exercise can improve antioxidant defense system of organis. But long and heavy exercise can disrupt the balance of oxidant-antioxidant. Low glutathione peroxidase is associated with free radicals. Plant purple sweet potatoes (Ipomoea batatas L.) contain anthocyanins high enough that act as antioxidants. This study aimed to determine the effect of extracts of tubers of purple sweet potato (Ipomoea Batatas L.) on the activity of glutathione peroxidase (GPx) liver of mice (Mus Musculus) treated with maximal physical exercise.

Subjects and Method: This was a true experimental study. This conducted with the design of the control group post-test only in vivo on 24 white male mice (Mus musculus), DD Webster strain. Data analysis was using SPSS software 19. Statistical testing decision taken $5 \%$ significance level $(\mathrm{p}=0.05)$.

Results: The results showed that the average enzyme activity of GPx in the $\mathrm{P}_{5}$ is the highest enzyme activity GPx (mean=19:39 $\pm \mathrm{SD}=7: 06, \mathrm{p}=0.024)$, which means there are significant differrences in the enzyme activity of GPx values between groups.

Conclusion: This study showed that the extract could increase the activity of GPx hepatic enzymees mice significantly.
\end{abstract}

Keywords: physical exercise maximum, free radicals, purple sweet potato, anthocyanin, GPx

Correspondence:

Ayu Elvana. School of Health Sciences (STIKes) Siti Hajar, Medan, Indonesia

\begin{abstract}
BACKGROUND
$\overline{\text { Physical exercise and or sport activity are }}$ efforts toincrease the degree of health (Depkes, 2014). American College and Sports Medicine recommends exercises to attain cardiorespiratory fitness and body trimness by regarding frequency, intensity, duration, and types of activity (Sastradipradja, 2014). Although exercise increases organism's antioxidant defense system, however, long period and heavy exercise will violate the balance between oxidant and antioxidant (Escribano et al., 2010).
\end{abstract}

During maximal physical exercise, free radicals' secretion especially superoxide may increase in mitochondria or energy centers within cells, whenever body cells use oxygen to produce energy, body cell may form reactive molecules (easily react) called free radicals (Daniel et al., 2010). Free radicals molecules are not stable because of electron deficiency on one of its atom. The unstable molecule will actively seek for electron pair for the atom with electron deficiency (Agarwal, 2005). It will very actively react with the existing molecules around. The free radicals reaction with the existing molecules within body often harm body cell (Cooper, 2001).

Bodyhas protection mechanism which neutralize created free radicals, among others with the existence of superoxide dis- 
mutase (SOD), catalase (CAT), and glutathione peroxidase (GPx) enzymes (Winarsi, 2007). Delmas-Beauvieaux et al (1996) reports that glutathione peroxidase enzyme more strongly decomposites $\mathrm{H}_{2} \mathrm{O}_{2}$ compared to catalase enzyme. Activity of glutathione peroxidase enzyme is able to reduce $70 \%$ of organic peroxide and more than 90\% of $\mathrm{H}_{2} \mathrm{O}_{2}$ (Winarsi, 2007).

Within liver and red blood cell exist high concentration of glutathione peroxidase, whereas heart, kidney, lungs, adrenal, stomach, and adipose tissue contain moderate level of glutathione peroxidase, low level of glutathione peroxidase is often found in brain, muscle, testicle, eye lens ( $\mathrm{Su}$ gianto, 2011). The activity of the enzyme may also be induced by isoflavones secondary antioxidant (Chen et al, 2002).

One of flavonoid components from plant that may function as antioxidant is natural color substance which is called anthocyanin (Simanjuntak, 2012). Based on his study Sugianto (2011) concludes that the administration of red pomegranate $(\mathrm{Pu}-$ nica granatum) that contains anthocyanin may increase glutathione peroxidase in the blood of mice (Mus musculus) with maximal physical exercise (Sugianto, 2011).

Based on study result of Agriculture Faculty Udayana University Bali it found purple sweet potato plant (Ipomoea batatas L.) whose tubers contain quite high anthocyanin that is about 110mg-210 mg/100 gram (Suprapta, 2004). The administration of local Balinese purple sweet potato extract which is either unprocessed or in a form of syrup, may protect liver tissue from free radicals as the result of maximal physical exercise on mice (Jawi, 2007).

\footnotetext{
SUBJECTS AND METHOD

Research Design

The study was purely experimental with research design post-test only, control group

design. Sample was divided into 6 groups each consisted of 5 mice. P1 as a control which did not endure any treatment at all only eat and drink in ad libitum. P2 endured maximal physical exercise which was swimming for 60 minutes and $0.5 \mathrm{ml} /$ mouse/day of aqua bidest orally. $\mathrm{P}_{3}$ got 0.5 $\mathrm{ml} /$ mouse/ day of purple sweet potato tuber extract orally. $\mathrm{P} 4$ got maximal physical exercise which was swimming for $60 \mathrm{~min}$ utes and $0.5 \mathrm{ml} / \mathrm{mouse} /$ day of purple sweet potato tuber extract orally. $\mathrm{P}_{5}$ got maximal physical exercise which was swimming for 60 minutes and $1 \mathrm{ml} /$ mouse/ day of purple sweet potato tuber extract orally. got maximal physical exercise which was swimming for 60 minutes and $1.5 \mathrm{ml} /$ mouse/ day of purple sweet potato tuber extract orally. The drenching of aqua bidest and purple sweet potato tuber extract were conducted 3 hours after swimming. All treatments were conducted for 14 days.

\section{Extract Making}

The tubers of purple sweet potato were rinsed with clean water peeled out and chopped crosswise with $2-2.5 \mathrm{~cm}$ of thickness. The chopped tubers were steamed for \pm 15 minutes. Afterward the tubers were cooled down and put in a glass jar to be fermented by adding tape starter (wine yeast) which was bought in traditional market. The fermentation was conducted for 36 hours. The result of fermentation (tapai) was mixed with clean drinking water with comparison $1 \mathrm{~kg}$ of fermented purple sweet potato (tapai) added by 1 liter of water and then blended and screened with gauze. The screening result was given to mice. The level of anthocyanin was measured by measuring the absorbance of purple color of anthocyanin by using spectrophotometer on $520 \mathrm{~nm}$ and $720 \mathrm{~nm}$. From the measuring it was obtained that the level of anthocyanin on fresh purple sweet potato 
was $9,984 \mathrm{mg} / 100 \mathrm{~g}$ and on fermented tubers was $89,666 \mathrm{mg} / 100 \mathrm{~g}$.

\section{Enzyme Activity Measurement}

After liver was separated from from the mouse body, liver was rinsed with $\mathrm{NaCl} 0.9 \%$. It was weighed $0.1 \mathrm{~g}$ and then put into homogenizer tube and kept in the the cool box with ice in it. Liver was crushed using homogenizer, and it was conducted in a cool box with ice in it. The crushed liver was added with $0.2 \mathrm{ml}$ of cold assay buffer solution. Afterward, it was centrifuged on $10.000 \mathrm{x}$ gravitation for 15 minutes in the temperature $4^{\circ} \mathrm{C}$. The produced supernatant would be used for the test. The examination of liver GPx was conducted with Glutathione Peroxidase Activity Colorimetric Assay Kit from Biovision and using spectrophotometer.

\section{Data Analysis}

The data was not normally distributed therefore Kruskall-Wallis was used. To observe the existence of differences between control group with treatment group Post-Hoc test was conducted. All data analysis was conducted by using SPSS 19 software. In this study for statistics test decision the significance level obtained was $5 \%(\mathrm{p}=0.05)$ which was considered significant

\section{RESULTS}

From the study result it obtained measuring data for Glutathione Peroxidase enzyme activity on mice's liverafter the treatment, as it is presented in Table 1. Based on Table 1 it is discovered that the mean of GPx enzyme activity on $\mathrm{P}_{5}$ group is the highest GPx enzyme activity that is $19.39 \pm$ 7.06, an then consecutively followed by $\mathrm{P}_{4}$ (7.05 \pm 8.19$), \mathrm{P}_{1}$ (6.58 \pm 7.04$), \mathrm{P}_{3}(4.50 \pm 4.31)$, $\mathrm{P} 6$ (3.03 \pm 1.98$)$, and P2 $(1.84 \pm 0.92)$ is the lowest GPx enzyme activity.

On Kruskal-Wallis test, it obtained the value of $\mathrm{p}=0.024$ that means there is significant difference of GPX enzyme activity value among groups since $\mathrm{p}<0.05$.

Table 1. Result of Glutathione Peroxidase enzyme activity value mean (GPx) on mice liver (Mus musculus L.) after 14 days of treatment

\begin{tabular}{lccc}
\hline Treatment Group & $\begin{array}{c}\text { Number of } \\
\text { Mice }\end{array}$ & Mean \pm SD (mU/ml) & p \\
\hline (P1) Mean & 4 & $6.58 \pm 7.04$ & \\
(P2) MPE & 4 & $1.84 \pm 0.92$ & \\
(P3) O.5 ml extract & 4 & $4.50 \pm 4.31$ & ${ }^{*} 0.024$ \\
(P4) MPE + 0.5 ml extract & 4 & $7.05 \pm 8.19$ & \\
(P5) MPE + 1 ml extract & 4 & $19.39 \pm 7.06$ & \\
(P6) MPE + 1.5 ml extract & 4 & $3.03 \pm 1.98$ & \\
\hline
\end{tabular}

Information :

MPE : Maximal Physical Exercise

${ }^{*} \mathrm{p} \leq 0.05$ the significance is different compared to positive control

\section{DISCUSSION}

In accordance with liver function as detoxification organ therefore damage on liver will lead to intoxication within the body. The early signs of liver function disorder can be conducted by measuring the value of enzyme activity (Musthofiyah, 2008).

This study found a significant differrent among the groups, in which in $\mathrm{P} 2$ there was significant reduction compared to control group (P1). It was because $\mathrm{P} 2$ was 
group that only received treatment of maximal physical exercise in 60 minutes for 14 days. Oxygen consumption by body during heavy exercise may increase up to two times or more (Thirumalai et al.) it is in accordance with the study conducted by Daniel et al. There was an increase on the activity level of SOD, CAT, and reduce GSH on liver after doing maximal physical exercise. Similarly with the study conducted by Lima et al., on exercise group it boosts the reduction of gluthatione (GSH), increases MnSOD, and reduces lipid peroxidase on liver mitochondria (Lima et al., 2013).

Under a high stress, within muscle fiber occurs the increase of oxygen use above normal need. The extraordinary oxygen needs may generate free radicals release in mitochondria that lead to increasing use of GPx within the body. It will reduce the amount of GPx within the body (Sugianto, 2011).

It was discovered from the data that $\mathrm{P}_{5}$ group that received treatment in a form of maximal physical exercise and the administration of purple sweet potato tubers extract had GPx enzyme activity value (19. $39 \pm 7.06)$ which was significantly different from $\mathrm{P} 1$ group (6.58 \pm 7.04$), \mathrm{P}_{3}(4.50 \pm 4.31)$, and $\mathrm{P} 6(3.03 \pm 1.98)$, whereas from $\mathrm{P}_{4}(4.5 \mathrm{O}$ \pm 4.31 , it had different value however it was not significant. On $\mathrm{P}_{5}$ there was significant increase on GPx enzyme activity that can be seen on table 1 and table 2, it is in accordance with the study conducted by Sugianto (2011) the administration of red pomegranate juice (Punica granatum) may increase the level of blood glutathione Peroxidase on mice (Mus musculus) with maximal physical activity. The study conducted by Hou et al (2010) found that the anthocyanin extract from black rice (Oryza sativa L. Japonica) was able to increase the level of blood glutathione peroxidase on the liver of male mice which were induced by alcohol for 45 days.

From the result of the study it can be concluded that the administration of purple sweet potato tubers extract in moderate dosage will increase GPx enzyme activity. In this study it found that the better dosage was $1 \mathrm{ml}$ of purple sweet potato tubers extract.

Based on the study it can be concludeed that the administration of purple sweet potato tubers extract in moderate dosage would increase enzyme GPx activity on the liver of mice. The study found that the better dosage was $1 \mathrm{ml}$ of purple sweet potato tubers extract. In which there was significant difference since $\mathrm{p}<0.005$.

\section{REFERENCE}

$\overline{\text { Agarwal A, Gupta S, Sharma RK (2005). }}$ Role of oxidative stress in female reproduction. Biol Reprod Endrocinol.

Chen CY, Holtzman GI, Bakhit RM (2002). High-genistin isoflavone supplementation modulated and Increased erythrocyte antioxidant enzymes in rats undergoing endurance running one session of exhausting exercisea pilot study. Pakistan Journal of Nutrition. 1(1).

Cooper K (2001). Healthy without drugs. Four steps antioxidant revolution that changed your life. Bandung: Kaifa.

MR Daniel, Dragomir C, Stelian S (2010). The effect of acute physical exercise on liver and kidney in the Wistar rat. Romanian biotechnological Letters 15 (3), Supplement. Copyright 2010 University of Bucharest.

Department of Health (2014). Improve community health status through exercise. www.depkes.go.id. Accessed on March 24, 2014.

Escribano BM (2010). Effects of an aerobic training program on oxidative stress 
Indonesian Journal of Medicine (2016), 1(2): 116-120

https://doi.org/10.26911/theijmed.2016.01.02.05

biomarkers in bulls. Veterinarni Medicina 55(9): 422-428.

Hou Zhaohua, Qin, Peiyou, Ren, Guixing (2010). Effect of anthocyanin-rich extract from black rice (Oryza sativa 1 . Japonica) on chronically alcohol-induced liver damage in rats. J. Agric. Food Chem. 2010, 58, 3191-3196. DOI: 10.1021 / jfgo4407x.

Jawi IM, Suprapta DN, Sutirtayasa IWP (2007). The antioxidant effect of extracts of tubers of purple sweet potato (Ipomoea batatas L) of the liver after physical activity with up to see the AST and ALT levels in the blood of mice. Dexa Media 20 (3).

Five DF (2001). Swimming training induces adaptations to liver mitochondrial oxidative stress in rats submitted to repeated bouts of exhaustive swimming. PLoS ONE 8(2): e55668.

Musthofiyah H (2008). Effect of papaya (Carica papaya) on levels of transaminase enzymes gutter-gpt and histology of liver of mice (Mus musculus) induced karbontetraklorida $(\mathrm{CCl} 4)$. Thesis, Malang: The Malang Islamic University, Biology, Faculty of Science and Technology.
Sastradipradja D (2014). Work physiology in animals sports. Denpasar: Udayana University, Department of Food Science Faculty of Animal Husbandry.

Simanjuntak K (2012). The role of antioxidant flavonoids in improving health. Jakarta, BINA WIDYA 23 (3): 135140.

Sugianto NL (2011). Giving juice red pomegranate (Punica granatum) can increase blood levels of glutathione peroxidase in mice (Mus musculus) with a maximum of physical activity. Thesis, Denpasar: Udayana University.

Suprapta DN (2004). Study aspects of breeding, cultivation and utilization of tubers as an alternative food source. Research Report. BAPEDA cooperation with the Faculty of Agriculture Bali Province UNUD.

Thirumalai T, Therasa SV, EK Elumalai, David E (2011). Intense and exhausttive exercise induced oxidative stress in skeletal muscle. Asian Pacific Journal of Tropical Disease: 63-66.

Winarsi H (2007). Natural Antioxidants and Free Radicals. Yogyakarta. Publisher Canisius. 